\title{
Physiological and technological aspects of large-scale heterologous-protein production with yeasts
}

\author{
M.C.M. Hensing ${ }^{1}$, R.J. Rouwenhorst ${ }^{2}$, J.J. Heijnen ${ }^{3}$, J.P. van Dijken ${ }^{1}$ \& J.T. Pronk ${ }^{1 *}$ \\ ${ }^{1}$ Department of Microbiology and Enzymology, ${ }^{3}$ Department of Bioprocess Engineering, Kluyver Laboratory of \\ Biotechnology, Delft University of Technology, Julianalaan 67, 2628 BC Delft, The Netherlands; ${ }^{2}$ Unilever \\ Research Laboratory, Olivier van Noortlaan 120,3133 AT Vlaardingen, The Netherlands; ${ }^{*}$ Corresponding \\ author)
}

Received 4 May 1994; accepted in revised form 2 September 1994

Key words: fed-batch fermentation, heterologous-protein production, large-scale fermentation, yeast

\begin{abstract}
Commercial production of heterologous proteins by yeasts has gained considerable interest. Expression systems have been developed for Saccharomyces cerevisiae and a number of other yeasts. Generally, much attention is paid to the molecular aspects of heterologous-gene expression. The success of this approach is indicated by the high expression levels that have been obtained in shake-flask cultures. For large-scale production however, possibilities and restrictions related to host-strain physiology and fermentation technology also have to be considered. In this review, these physiological and technological aspects have been evaluated with the aid of numerical simulations. Factors that affect the choice of a carbon substrate for large-scale production involve price, purity and solubility. Since oxygen demand and heat production (which are closely linked) limit the attainable growth rate in large-scale processes, the biomass yield on oxygen is also a key parameter. Large-scale processes impose restrictions on the expression system. Many promoter systems that work well in small-scale systems cannot be implemented in industrial environments. Furthermore, large-scale fed-batch fermentations involve a substantial number of generations. Therefore, even low expression-cassette instability has a profound effect on the overall productivity of the system. Multicopy-integration systems may provide highly stable expression systems for industrial processes. Large-scale fed-batch processes are typically performed at a low growth rate. Therefore, effects of a low growth rate on the physiology and product formation rates of yeasts are of key importance. Due to the low growth rates in the industrial process, a substantial part of the substrate carbon is expended to meet maintenance-energy requirements. Factors that reduce maintenance-energy requirements will therefore have a positive effect on product yield. The relationship between specific growth rate and specific product formation rate (kg product $[\mathrm{kg} \text { biomass }]^{-1} \cdot \mathrm{h}^{-1}$ ) is the main factor influencing production levels in large-scale production processes. Expression systems characterized by a high specific rate of product formation at low specific growth rates are highly favourable for large-scale heterologous-protein production.
\end{abstract}

\section{Introduction}

In comparison with bacterial systems, yeasts have a number of advantages as hosts for heterologous protein production. Yeasts can excrete many proteins into the growth medium in a soluble and biologically active form, which may greatly facilitate purification. Furthermore, as eukaryotic organisms, yeasts are capable of post-translational modification of proteins, such as glycosylation and/or other modifications required for optimal biological activity and stability.

Some yeasts, including Kluyveromyces marxianus var.marxianus, $K$. marxianus var. lactis and Saccharomyces cerevisiae are commonly used in the food industry and have obtained a GRAS (generallyregarded-as-safe) status. This is a major advantage for applications in the food or pharmaceutical industry, since less extensive trials are required by the regulato- 
ry authorities. Also the well-established, cost-effective fermentation technology available for a number of yeasts is an incentive for their application as hosts for heterologous-protein production.

S. cerevisiae was originally the model organism for heterologous-gene expression in yeasts. The first heterologous gene product expressed in S. cerevisiae was rabbit $\beta$-globulin (Beggs et al. 1980). Subsequently, research has been extended to other yeasts, selected because of favourable genetic, physiological or fermentation properties. Currently, numerous foreign genes have been expressed in a variety of yeast species (Reiser et al. 1990, Romanos et al. 1992).

The tremendous advances in yeast molecular genetics have yielded a wide range of vectors, selection markers, promoters, terminators and secretion signals for expression of heterologous genes. As a result of the expanding knowledge in this area, many problems encountered in the expression of foreign genes can be understood and solved (for recent reviews, see Romanos et al. 1992, Buckholz \& Gleeson 1991, Gellissen et al. 1992). At present, however, most processes for heterologous-protein production by yeasts are still in the development phase. Consequently, most papers on the subject deal with molecular-genetic aspects and production at millilitre scale.

According to current expectation (Newmark 1989) most classical enzymes produced by yeasts will have been substituted by recombinant-DNA products by the end of this century. At present however, little information is available from the literature on heterologousprotein production under conditions relevant for such large-scale industrial processes. For example, information on fed-batch studies into the physiological and technological aspects of heterologous-protein production is scarce, a deficiency that is partially caused by the commercial interest in this field.

The aim of this paper is to discuss factors relevant for heterologous-protein production by yeasts, both from a theoretical and a practical point of view. To illustrate the influence of environmental and physiological parameters, and to assess the applicability of various expression systems in an industrial environment, simulated large-scale $\left(100 \mathrm{~m}^{3}\right)$ fed-batch fermentations are used as examples.

\section{Cultivation methods}

Three cultivation methods can be considered for the production of heterologous proteins by yeasts: batch, fed-batch and continuous cultivation. In order to be commercially viable, any cultivation method has to meet a number of criteria. These include a high volumetric productivity, a high final product concentration, stability and reproducibility of the process and the applicability of low-cost, highly soluble substrates. Legal restrictions, e.g. those related to the application of recombinant-DNA techniques, also constitute an important factor.

Notwithstanding their usefulness in laboratory environments, batch cultures are not suited for largescale production. High initial sugar concentrations cause catabolite-repression phenomena and in some yeasts, including $S$. cerevisiae, trigger alcoholic fermentation even when oxygen is present (Fiechter et al. 1981; van Dijken \& Scheffers 1986). Since, in batch cultures, the growth rate cannot be controlled, growth rapidly becomes limited by oxygen. When sugars are used as a feedstock, this triggers alcoholic fermentation, resulting in a reduction of the biomass yield and a concomitant decrease in product formation. Furthermore, osmotic sensitivity of the yeasts sets a limit to the initial concentration of nutrients.

During fed-batch and continuous cultivation, the growth rate can be manipulated by controlled addition of substrate. Thus, byproduct formation and cataboliterepression phenomena can be avoided and oxygen uptake and heat generation can be adapted to the limitations set by the reactor specifications.

Industrial applications of continuous cultivation are few, and include production of glucose isomerase (Diers 1976), production of beer (Hough et al. 1976) and some dairy products (Lelieveld 1984). These processes are characteristically run at high dilution rates, resulting in a high volumetric productivity. Restrictions with respect to oxygen transfer and cooling capacity, however, limit the cell densities that can be attained at high dilution rate. Therefore, the advantage with respect to overall productivity is not as large as often supposed (Heijnen et al. 1992). During prolonged cultivation, accumulation of less- or non-producing variants may lead to a decreased productivity. Prolonged maintenance of axenic conditions may also be a problem, for example during replacement of malfunctioning equipment. These considerations have resulted in fed-batch cultivation being the generally preferred method for large-scale production of heterologous proteins by yeasts.

During fed-batch cultivation of yeasts, nutrients are continuously fed to a culture, while biomass and product are retained in the reactor until the process is 
terminated. Although in principle all essential nutrients may be added continuously, in practice feeding is mostly restricted to a limited number of components, notably the carbon source (Beudeker et al. 1990). The theory of fed-batch cultivation and its advantages for the production of biomass and microbial products have been amply reviewed (Pirt 1974, Yamanè and Shimizu 1984).

Fed-batch cultivation is initiated by the transfer of an inoculum from a seed reactor to the production reactor. Initially, all nutrients are available in excess, and growth proceeds exponentially until the growthlimiting substrate is depleted. Due to the short duration of this batch phase and the relatively low amount of biomass present, only a limited amount of product is formed.

After the batch phase a concentrated feed, containing the carbon source and other nutrients, is continuously fed to the reactor. The feed rate is the key control parameter for fed-batch cultivation and determines the growth rate and the associated oxygen consumption and heat generation. Depending on the scale of the process, either oxygen transfer into the culture or heat transfer from the culture (cooling) will limit the maximum attainable feed rate. Feed-control regimes to prevent oxygen limitation can be either precalculated or subjected to feed-back control.

In feed-back control systems for $S$. cerevisiae, occurrence of alcoholic fermentation can be used as indication for oxygen limitation or sugar excess. For example, for the production of pro-urokinase in S. cerevisiae, the feed rate was regulated by maintaining the ratio of carbon dioxide production to oxygen consumption (RQ) below a critical value (Turner et al. 1991). Alberghina et al. (1991) used a feed-back control coupled to measurement of ethanol in the outgoing gas for the production of $\beta$-galactosidase.

Due to the limitations imposed by the oxygenand/or heat-transfer properties of the reactor, exponential growth cannot be sustained. Therefore, a decreasing growth rate is a characteristic of all large-scale fed-batch processes. An important consequence of the decreasing growth rate is that the relative amount of substrate required for maintenance purposes will increase (Pirt 1965, Stouthamer \& van Verseveld 1987).

\section{Scale considerations}

Expression of heterologous proteins in yeasts provides a powerful tool for laboratory studies into the structure and function of heterologous proteins, in particular from higher eukaryotes and eukaryotic viruses. For this application, large-scale cultivation is usually not required.

The industrial production of heterologous proteins in yeasts is aimed at two market sectors: pharmaceutical proteins and industrial enzymes, the latter mainly for food-related applications. A logarithmical relationship between annual market size and price of proteins has been reported in the literature (Hacking 1986, Arbige \& Pitcher 1989). Based on market size and price, heterologous proteins can be divided in three classes (Poldermans 1989). Bulk proteins typically cost \$5-100 kg-1 and have an annual market of $10^{5}$ $10^{7} \mathrm{~kg}$. Specialty proteins have a higher price $(>\$ 100$ $\mathrm{kg}^{-1}$ ) and an annual market of $10^{3}-10^{5} \mathrm{~kg}$. The most expensive class (typically $>\$ 1000 \mathrm{~kg}^{-1}$ ) comprises medical and analytical proteins with an annual market size of $1-10^{3} \mathrm{~kg}$. The market size is the key factor that determines the industrial scale on which a heterologous protein is produced. In general, high-price proteins are produced at $0.1-5 \mathrm{~m}^{3}$ scale, medium-value proteins in reactors with a volume of $1-50 \mathrm{~m}^{3}$ and bulk proteins in reactors with a volume of $100 \mathrm{~m}^{3}$ or more.

Human-serum-albumin (HSA) production in yeasts provides an illustration of the fermentation infrastructure required for the production of heterologous 'bulk' proteins. HSA has a clinical application in the treatment of shocks, burns and blood losses. Its estimated annual market is $3 \times 10^{5} \mathrm{~kg}$ at a price of approximately $\$ 2000 \mathrm{~kg}^{-1}$ (Fleer et al. 1991). Assuming that a product concentration of $2.5 \mathrm{~kg} \cdot \mathrm{m}^{-3}$ can be achieved in $100 \mathrm{~m}^{3}$ fermentations, and disregarding losses during down-stream processing, 1200 of such large-scale fermentations are required to meet the annual world-wide demand. Nevertheless, the scaling-up of shake-flask cultivation by a factor of one million to a $100 \mathrm{~m}^{3}$-scale industrial process is a major challenge that has received little attention in the literature.

\section{Hosts}

S. cerevisiae is the best-characterized host for heterologous-protein production in yeasts. The popularity of $S$. cerevisiae is in first instance due to the fact that knowledge about its molecular genetics is 
more extensive than for other yeasts. According to recent reviews (Romanos et al. 1992, Heinisch \& Hollenberg 1993), over 100 heterologous proteins have been expressed in $S$. cerevisiae. $S$. cerevisiae has a GRAS status and large-scale fermentation processes have been developed for the production of this yeast. Nevertheless, production of the vast majority of the heterologous proteins produced in $S$. cerevisiae has only been reported for shake-flask cultures.

Interest in the methylotrophic yeasts Hansenula polymorpha and Pichia pastoris as hosts for heterologous protein production stems from the extensive research on these organisms that was aimed at the production of single-cell protein (SCP). Research on SCP production has yielded valuable information on the large-scale cultivation of these organisms on methanol. Biochemical and physiological research on these organisms has shown that under methanolinduced conditions, up to $30 \%$ of the cell protein may consist of a single protein: alcohol oxidase (Van Dijken et al. 1976; Veenhuis et al. 1983; Couderc \& Barratti 1980; Giuseppin et al. 1988). Alcohol oxidase is the product of the MOXI (H. polymorpha; Ledeboer et al. 1985) or AOXI (P. pastoris; Ellis et al. 1985) gene. The methanol-inducible promoters of these genes are very powerful and have been successfully applied for the production of a variety of heterologous proteins (Romanos et al. 1992).

Like $S$. cerevisiae, Kluyveromyces yeasts have a long history in classical biotechnology, in particular for the production of $\beta$-galactosidase. These yeasts have a GRAS status and are now well accessible for molecular genetic techniques. They are used for the production of a number of heterologous proteins (Romanos et al. 1992), including bovine chymosin, a milk-clotting enzyme used in cheese manufacturing (van den Berg et al. 1990).

Large-scale industrial processes have also been developed in the past for Yarrowia lipolytica, in particular for the production of citric acid and SCP. Homologous proteins, including proteases (Yamada \& Ogrydziak 1983, Matoba \& Ogryd- ziak 1989) and RNase (Cheng \& Ogrydziak 1986) can be secreted at high levels by this yeast. At present, all data available on heterologous-protein production by this $Y$. lipolytica refer to shake-flask cultures (Heslot 1990). The same holds for Schizosaccharomyces pombe (Romanos et al. 1992), a yeast of which the molecular genetics have been extensively studied.

\section{Media and carbon substrates}

Complex carbon substrates, and in particular molasses, are popular feedstocks for the large-scale cultivation of yeasts. A disadvantage of molasses is that the disposal of spent medium is becoming increasingly expensive due to environmental legislation.

The choice between complex and defined media is to a large extent determined by the nature of the heterologous product. For the production of low-cost industrial enzymes, complex media are preferred because of their low price. However, very strict demands are imposed on the purity of products with a pharmaceutical application. In such cases, use of defined media can greatly reduce the costs of down-stream processing. For example, large-scale production of recombinant HSA in $S$. cerevisiae will be based on defined mineral media containing salts, vitamins and sugar (Goodey 1993). With defined media, optimum benefit can be obtained from the advantages in down-stream processing that are offered by the secretion of heterologous proteins. The advantage of defined media is less pronounced when a product is accumulated intracellularly and complex medium components can be removed by extensive washing of the biomass.

Prices of carbon sources for the cultivation of yeasts vary significantly as a function of crop yields, gas prices and governmental subsidies. The data presented in Table 1 give an indication of the relative prices of a number of relevant feedstocks. Based on price alone, glucose, sucrose (molasses) and methanol appear to be the best choices as substrates for large-scale fermentations.

Water economy is also a key issue in commercial protein production. Especially when proteins are produced extracellularly, high product concentrations will greatly reduce the costs of down-stream proces- sing. This in turn requires high biomass densities and the use of highly concentrated carbon-substrate feeds. Price and solubility are not the only important considerations: in particular cooling and oxygen transfer are key bottlenecks in large-scale fermentation processes. During aerobic growth, heat production and oxygen consumption are closely correlated: for each mole of oxygen consumed, $455 \mathrm{~kJ}$ heat is generated (Roels 1983). The amount of oxygen required during growth on various substrates can be calculated from balance equations (Roels 1983, Stouthamer \& van Verseveld $1985,1987)$. For example, aerobic growth on glucose can be described by the equation: $1.111 \mathrm{C}_{6} \mathrm{H}_{12} \mathrm{O}_{6}+$ $0.800 \mathrm{NH}_{4}{ }^{+}+2.516 \mathrm{O}_{2} \rightarrow 1.000 \mathrm{C}_{4} \mathrm{H}_{7} \mathrm{O}_{2} \mathrm{~N}_{0.8}(100$ 
Table 1. Water solubility, prices and biomass yields for a number of fermentation substrates. Solubility data have been obtained from Graefe (1975). Prices are from Präve et al. (1990); asterisks indicate EC-subsidized prices. Biomass yields are presented as $\mathrm{Y}_{s x}(\mathrm{~kg}$ biomass $\cdot[\mathrm{kg} \text { substrate }]^{-1}$ ) and $Y_{o x}\left(\mathrm{~kg}\right.$ biomass $\left.\cdot[\mathrm{kg} \text { oxygen }]^{-1}\right)$ and refer to data from carbon-limited, aerobic chemostat studies obtained in our laboratories.

\begin{tabular}{lllll}
\hline Substrate at & $\begin{array}{l}\text { Solubility } \\
25^{\circ} \mathrm{C} \mathrm{kg} \cdot \mathrm{m}^{-3}\end{array}$ & $\begin{array}{l}\text { Price Ecu. } \\
\mathrm{kg}^{-1}\end{array}$ & $\begin{array}{l}\mathrm{Y}_{\varepsilon x} \mathrm{~kg} \text { biomass. } \\
{[\mathrm{kg} \text { substrate }]^{-1}}\end{array}$ & $\begin{array}{l}\mathrm{Y}_{\text {ox }} \mathrm{kg} \text { biomass. } \\
{[\mathrm{kg} \text { oxygen }]^{-1}}\end{array}$ \\
\hline fructose & 810 & 1.5 & 0.5 & 1.2 \\
glucose & 510 & $0.3^{*}$ & 0.5 & 1.2 \\
glycerol & 1260 & 1.3 & 0.58 & 1.3 \\
lactose & 160 & $0.9^{1}$ & 0.5 & 1.2 \\
methanol & 790 & 0.15 & 0.37 & 0.4 \\
sucrose & 670 & $0.3^{* 1}$ & 0.5 & 1.2 \\
\hline
\end{tabular}

${ }^{1}$ Whey and molasses are cheaper sources of lactose and sucrose, respectively. Based on sugar content, molasses are approximately four-fold cheaper than sucrose.

g biomass $)+2.666 \mathrm{CO}_{2}+0.800 \mathrm{H}^{+}+4.366 \mathrm{H}_{2} \mathrm{O}$. For each ammonium ion consumed, one proton is produced. By using ammonium hydroxide as a titrant, controlled addition of the nitrogen source can be achieved. Furthermore, the osmotic stress that would occur by the use of sodium or potassium hydroxide as titrant is circumvented.

The oxygen requirement during respiratory growth is stoichiometrically coupled to the biomass yield on the carbon substrate ( $\mathrm{Y}_{s x}, \mathrm{~kg}$ biomass. $[\mathrm{kg}$ substrate $]^{-1}$ ). The high oxygen requirement for growth on methanol (Table 1) compares unfavourably with growth on sugars and glycerol. Glycerol is unsuitable as a feedstock for large-scale yeast fermentations, because of its high price, an argument that also holds for fructose and lactose (Table 1). Lactose has the additional disadvantage of a low solubility and can therefore not be used for high-cell-density processes. Taking together price, solubility and biomass yields, sucrose (or molasses) and glucose are the preferred substrates for large-scale yeast fermentations.

\section{Specific rates of heterologous-protein production in yeasts}

In particular in shake-flask studies, the success of heterologous-protein production with yeasts is generally judged by the product concentration in the culture fluid at the time of harvest. In some cases, the product concentration has been related to the biomass concentration present at end of growth. If however the time span over which product formation occurs is not giv- en, such data can at best give a rough estimate of the specific product formation rate. The volumetric productivity of cultures can not easily be used to compare different expression systems either because, depending on medium composition and other growth parameters, biomass concentrations may differ by as much as two orders of magnitude. To compare literature data obtained with various expression systems, the specific production rate $\mathrm{q}_{p}$ ( $\mathrm{kg}$ product $\cdot[\mathrm{kg} \text { biomass }]^{-1} \cdot \mathrm{h}^{-1}$ ) has to be taken into account (Stouthamer \& van Verseveld 1985, 1987).

In Table 2, an overview has been given of $\mathrm{q}_{p}$ 's for the production of a number of heterologous proteins by yeasts under defined growth conditions. The simplest experimental system for the determination of $q_{p}$ is continuous cultivation at a constant dilution rate. In this case, $q_{p}$ is equal to $D \cdot C_{p} \cdot C_{x}{ }^{-1}$, in which $D$ is the dilution rate, $C_{p}$ is the product concentration and $C_{x}$ is the biomass concentration. In fed-batch and biomassrecycling cultures (van Verseveld et al. 1986), calculation of $q_{p}$ is somewhat more complicated because biomass concentration, growth rate and culture volume are continuously changing. Perhaps for this reason, $\mathrm{q}_{p}$ is not given as a process parameter in many studies on fed-batch cultivation. In a number of cases, $\mathrm{q}_{p}$ has therefore been calculated from the available literature data. When biomass yields and fermentation regimes had to be reconstructed from graphs, this may caused some inaccuracy in the estimated $q_{p}$ 's given in Table 2.

The specific production rates presented in Table 2 have been derived from literature data obtained with different yeasts, expression systems and fermentation 
Table 2. Specific rates of product formation $\left(\mathrm{q}_{p}\right)$ in fed-batch and continuous cultures of various yeasts expressing heterologous genes. When specific rates of product formation were not given by the authors, they were estimated by iterative simulation of fed-batch processes. This sometimes involved the assumption of growth yields and feed regimes.

\begin{tabular}{|c|c|c|c|c|c|}
\hline Host & Product & Localization $^{1}$ & $\begin{array}{l}\text { Culture } \\
\text { method }^{2}\end{array}$ & $\begin{array}{l}\mathrm{q}_{p} \\
\mathrm{~g} \cdot \mathrm{kg}^{-1} \cdot \mathrm{h}^{-1}\end{array}$ & Reference \\
\hline \multirow[t]{6}{*}{ S. cerevisiae } & $\alpha$-galactosidase & $\mathrm{E}, \mathrm{I}$ & $\mathrm{C}$ & 4.5 & Giuseppin et al. 1993 \\
\hline & $\beta$-galactosidase & $I$ & FB & 1.2 & Alberghina et al. 1991 \\
\hline & tissue plasminogen activator & I & FB & 0.03 & Martegani et al. 1992 \\
\hline & hepatitis-B surface antigen & I & FB & 0.03 & Gu et al. 1991 \\
\hline & proinsulin-SOD fusion & I & FB & 0.5 & Tøttrup \& Carlsen 1990 \\
\hline & $\gamma$-interferon & I & FB & 0.15 & Fieschko et al. 1987 \\
\hline \multirow[t]{4}{*}{ H. polymorpha } & $\alpha$-galactosidase & $\mathrm{E}, \mathrm{I}$ & $\mathrm{C}$ & 5.5 & Giuseppin et al. 1993 \\
\hline & glucoamylase & $\mathrm{E}$ & $\mathrm{FB}$ & 0.29 & Gelissen et al. 1991 \\
\hline & glucose oxidase & $\mathrm{E}, \mathrm{I}$ & FB & 0.95 & Hodgkins et al. 1993 \\
\hline & hepatitis-B-surface antigen & I & $\mathrm{C}$ & 0.15 & Janowicz et al. 1988 \\
\hline \multirow[t]{10}{*}{ P. pastoris } & tetanus-toxin fragment $C$ & I & FB & 1.8 & Clare et al. 1991a \\
\hline & pertactin p69 & I & FB & 0.5 & Romanos et al. 1991 \\
\hline & invertase & $\mathrm{E}$ & FB & 0.41 & Tschopp et al. 1987 \\
\hline & hepatitis-B-surface antigen & I & FB & 0.05 & Cregg et al. 1987 \\
\hline & lysozyme & $\mathrm{E}$ & $\mathrm{C}$ & 0.18 & Digan et al. 1989 \\
\hline & lysozyme & $\mathrm{E}$ & FB & 0.22 & Digan et al. 1989 \\
\hline & tumor-necrosis factor (TNF) & I & $\mathrm{C}$ & 4.3 & Sreekrishna et al. 1989 \\
\hline & TNF & I & FB & 0.8 & Sreekrishna et al. 1989 \\
\hline & streptokinase & I & $\mathrm{C}$ & 0.01 & Hagenson et al. 1989 \\
\hline & epidermal growth factor & $\mathrm{E}$ & FB & 0.07 & Clare et al. 1991b \\
\hline$K$. lactis & human serum albumin & $\mathbf{E}$ & FB & $1.1-1.5$ & Fleer et al. 1991 \\
\hline
\end{tabular}

${ }^{1} \mathrm{I}$, intracellular; E, extracellular. ${ }^{2} \mathrm{C}$, chemostat cultivation; FB, fed-batch fermentation

strategies. Nevertheless, the fact that the specific production rates vary by one order of magnitude for both fed-batch and chemostat cultures indicates that, in the case of some products, there is considerable room for improvement. Even in cases in which an identical host strain and expression system are used, as in the case of pertactin and tetanus-toxin-fragment- $\mathrm{C}$ production in Pichia pastoris (Table 2), substantially different $\mathrm{q}_{p}$ 's have been observed. These differences probably have to be attributed to intrinsic features of the heterologous proteins (stability, toxicity, etc.) or their coding DNA and/or RNA sequences (codon usage, secondary structures, etc.). As long as the molecular mechanisms responsible for such differences are not fully understood, screening of hosts and expression vectors will remain an essential step in the development of commercial processes for heterologous protein production.

\section{Simulation of heterologous-protein production in fed-batch cultures}

The effect of physiological and technological parameters on the productivity of large-scale yeast fermentations can be investigated and illustrated by numerical simulation. To this end, a $100 \mathrm{~m}^{3}$-scale fed-batch process for the production of heterologous proteins is considered. The growth parameters used in the simulations are based on literature data on sugarlimited growth of yeasts in defined media containing ammonium salts as a sole source of nitrogen. The default values for the relevant physiological and technological parameters are presented in Table 3 . It was attempted to choose realistic values based on the available literature. However, a wide variety of process parameters are used in practice. Therefore, the simulations should not be used to make quantitative predictions on the behaviour of real-life systems.

In the reference fermentation, we have introduced a number of simplifications. The $\mathrm{q}_{p}$ was assumed to be 
Table 3. Default values for relevant process parameters used in the numerical simulation of a large-scale production process for the production of heterologous proteins in yeasts. The biomass composition was taken as $\mathrm{C}_{4} \mathrm{H}_{7} \mathrm{O}_{2} \mathrm{~N}_{0.8}$ (Roels 1983). The PSI-c program used for the simulations is given in Appendix 1.

\begin{tabular}{llll}
\hline Process parameter & Symbol & Default value & Literature reference \\
\hline Initial volume & $\mathrm{V}_{0}$ & $50 \mathrm{~m}^{3}$ & \\
Final volume & $\mathrm{V}$ & $100 \mathrm{~m}^{3}$ & \\
Initial biomass concentration & $\mathrm{C}_{x 0}$ & $10 \mathrm{~kg} \cdot \mathrm{m}^{-3}$ & \\
Initial product concentration & $\mathrm{C}_{p 0}$ & $0 \mathrm{~kg} \cdot \mathrm{m}^{-3}$ & \\
Sugar concentration in feed & $\mathrm{C}_{s i}$ & $500 \mathrm{~kg} \cdot \mathrm{m}^{-3}$ & \\
Maximum oxygen-transfer rate & $\mathrm{r}_{O 2, \max }$ & $100 \mathrm{~mol} \cdot \mathrm{m}^{-3} \cdot \mathrm{h}^{-1}$ & van 't Riet 1983 \\
Initial feed rate & $\mathrm{F}_{0}$ & $0.5 \mathrm{~m}^{3} \cdot \mathrm{h}^{-1}$ & \\
Biomass yield on sugar & $\mathrm{Y}_{s x}$ & $0.5 \mathrm{~kg} \cdot \mathrm{kg}$ & Verduyn 1991 \\
Substrate requirement for maintenance & $\mathrm{m}_{s}$ & $0.024 \mathrm{~kg} \cdot \mathrm{kg}^{-1} \cdot \mathrm{h}^{-1}$ & Roels 1983 \\
Oxygen requirement for maintenance & $\mathrm{m}_{o}$ & $0.026 \mathrm{~kg} \cdot \mathrm{kg}^{-1} \cdot \mathrm{h}^{-1}$ & Roels 1983 \\
Specific product-formation rate & $\mathrm{q}_{p}$ & $2 \cdot 10^{-3} \mathrm{~kg} \cdot \mathrm{kg}^{-1} \cdot \mathrm{h}^{-1}$ & Table 2 \\
\hline
\end{tabular}

constant at $2 \mathrm{~g} \cdot[\mathrm{kg} \text { biomass }]^{-1} \cdot \mathrm{h}^{-1}$. The batch phase was not included in the simulation and the amount of heterologous protein formed during this phase was neglected. The low oxygen requirement for product formation, was not taken into account. Since a sugarlimited system was considered, the residual substrate concentration in the culture was assumed to be negligible.

The increase of the culture volume that occurs during the simulated feed phase causes a proportional increase of the amount of oxygen that can be transferred into the culture. For comparative purposes, the length of the fermentation time was kept at $90 \mathrm{~h}$ in all simulated fermentations. Consequently, the feed rate, which was given an initial value of $0.5 \mathrm{~m}^{3} \cdot \mathrm{h}^{-1}$ was allowed to increase according to the equation $\mathrm{F}=0.5$ $+(0.00124 \cdot t)$, in which $F$ is the feed rate $\left(\mathrm{m}^{3} \cdot \mathrm{h}^{-1}\right)$ at time $\mathrm{t}(\mathrm{h})$. During the simulated process, the oxygentransfer rate did not exceed 100 mole $\mathrm{m}^{-3} \cdot \mathrm{h}^{-1}$.

The program used for the simulations was written in the simulation language PSI-c, and is presented in Appendix 1. When the default parameter values presented in Table 3 were used to simulate a $100 \mathrm{~m}^{3}$ process for the production of a heterologous protein, the fermentation followed the pattern shown in Fig. 1. As a result of the chosen feed strategy, the specific growth rate continuously decreases during the process, from an initial value of $0.24 \mathrm{~h}^{-1}$ to ca. $0.01 \mathrm{~h}^{-1}$. After approximately $40 \mathrm{~h}$, maintenance requirements start to have a significant effect on biomass yields (Fig. 1). However, the total amount of biomass continues to increase and the biomass concentration reaches a maximum of 79

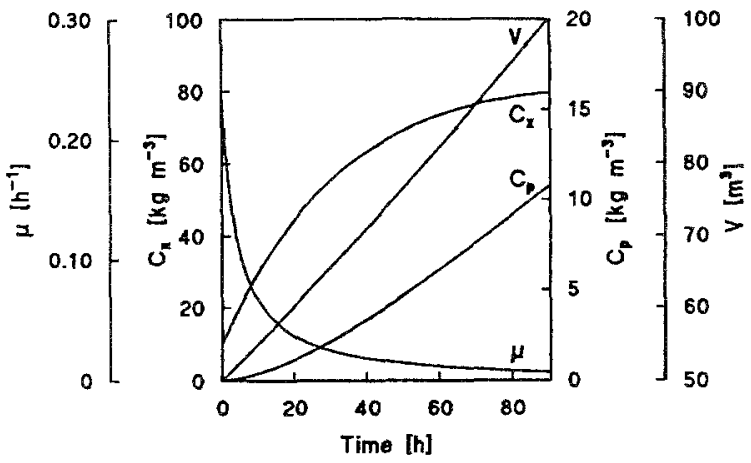

Fig. 1. Simulation of a $100 \mathrm{~m}^{3}$ fed-batch process for the production of a heterologous protein in yeast. The process parameters used for the simulation are given in Table 1, the PSI program used for the simulation is presented in Appendix 1.

$\mathrm{kg} \cdot \mathrm{m}^{-3}$ after $90 \mathrm{~h}$ of fermentation, at which time the reactor is filled to capacity $\left(100 \mathrm{~m}^{3}\right)$. At the end of the process, the total yield of the heterologous protein was $1.07 \cdot 10^{3} \mathrm{~kg}$. This corresponds to a product concentration of $10.7 \mathrm{~g} \cdot(1 \text { culture broth })^{-1}$ (Fig. 1). It should be realized that the product concentration in the cellfree supernatant will be significantly higher because, in high-cell-density fermentations, a substantial fraction of the culture volume is occupied by biomass. 


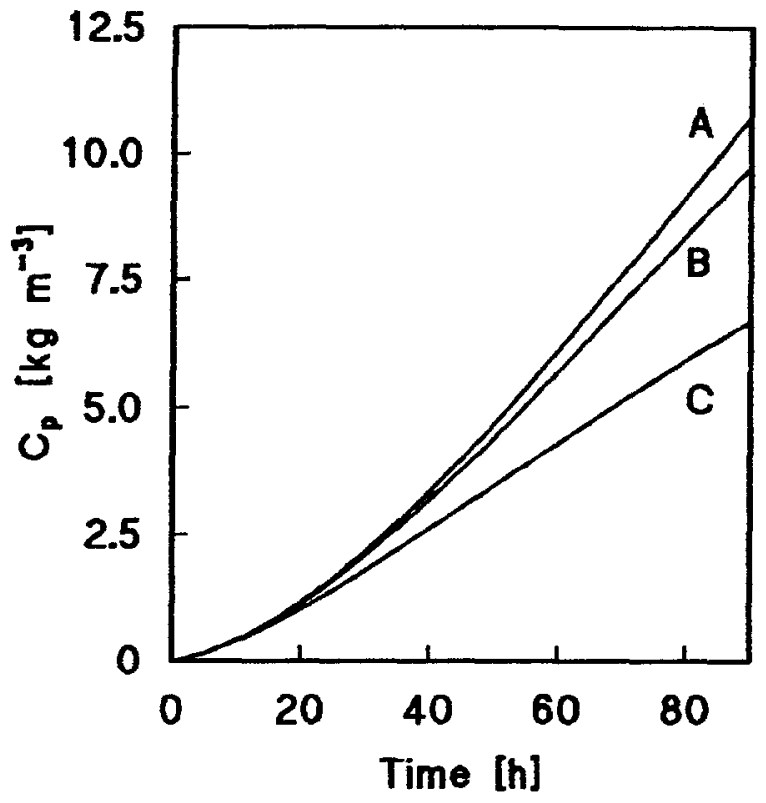

Fig. 2. Effect of expression-cassette stability on heterologous-protein production in a simulated $100 \mathrm{~m}^{3}$ fed-batch process (process parameters are presented in Table 1). Expression-cassette loss rates of $0(\mathrm{~A}), 1$ (B) and $5 \%$ per generation (C) were simulated.

\section{Stability of expression cassettes}

\section{Impact of expression-cassette stability on productivity}

On average, the route from stock culture to the final stage of an industrial-scale fed-batch cultivation requires about 35 generations. If the expression cassette is lost during the process, this will result in a loss of productivity. The negative effect of instability on the overall productivity is enhanced by the fact that most of the heterologous product is formed during the final stages of the process (Fig. 1).

Loss of expression cassettes can be caused by two distinct mechanisms: segregational instability and structural instability. Segregational instability encompasses the complete loss of the expression vector during cell division. Structural instability is the loss of heterologous gene expression due to changes in the DNA sequence, either by deletions, insertions or rearrangements. In both cases, instability results in the formation of non- or less-producing mutants.

To investigate the impact of expression-vector stability on large-scale heterologous-protein production, fed-batch processes using expression cassettes with different stabilities were simulated (Fig. 2). When loss rates of 1 and $5 \%$ per generation were introduced into the reference process (which involves 17 generations), this had a significant impact on the predicted productivity. As expected, the difference between high- and low-stability expression systems becomes particularly apparent during the final stages of the fermentation (Fig. 2). The observation that even a loss rate of $1 \%$ per generation resulted in an $8.4 \%$ decrease of the final product concentration (Fig. 2) clearly illustrates the importance of expression-cassette stability. This importance will become even more pronounced when the effect of instability in the steps that precede the fed-batch phase is taken into account.

\section{Episomal and integrating expression vectors}

All episomal vectors that have been successfully used for the expression of heterologous proteins in yeasts are circular plasmids carrying a yeast origin of replication (Romanos et al. 1992). The nature of the origin of replication is a key factor in determining the stability of episomal vectors. Vectors based on yeast ARS (autonomously replicating sequences) origins, derived from yeast chromosomes, are available for all yeast species, currently used as hosts for the expression of heterologous proteins (Romanos et al. 1992). Although some of these vectors have high copy numbers, their stability is generally low (loss rates are often in the order of $10 \%$ per generation). This low stability makes ARS-derived plasmids unsuited for application in large-scale processes.

A second class of episomal vectors is derived from naturally occurring yeast plasmids. The most extensively studied plasmid of this type is the $S$. cerevisiae $2 \mu \mathrm{m}$ plasmid (for a review see Futcher 1988). $2 \mu \mathrm{m}$ derived vectors can be maintained in $S$. cerevisiae at a very high copy number. Stability of $2 \mu \mathrm{m}$-derived vectors under non-selective conditions depends on various factors, including the presence of native plasmids (Futcher \& Cox 1984) and the insertion of foreign DNA (Bijvoet et al. 1991).

A $2 \mu \mathrm{m}$-like plasmid called pKD1 occurs in Kluyveromyces drosophilarum (Falcone et al. 1986, Bianchi et al. 1991) and can be replicated in a variety of Kluyveromyces species, including $K$. lactis. Under non-selective conditions, stability of pKD1-derived plasmids depends strongly on the host strain (Fleer et al. 1991). After ten generations of non-selective growth, plasmid loss varied between 10 and $80 \%$. Bergkamp et al. (1992) used a pKD1-derived vector 
for expression of guar $\alpha$-galactosidase in $K$. lactis and observed a complete loss of the vector after 70 generations.

After prolonged cultivation under non-selective conditions, instability becomes a problem with all episomal expression vectors currently available. A much higher stability can be achieved by recombinative integration of expression vectors in the yeast genome. Stability of integrating vectors is generally very high (loss rates are usually far below $1 \%$ per generation). Until recently, a major disadvantage of integrating vectors was their low copy number. This has changed with the development of techniques for multiple integration of expression cassettes.

The ribosomal DNA (rDNA) cluster of $S$. cerevisiae occurs in approximately 100-200 tandemly repeated units of $9.1 \mathrm{~kb}$ (Warner 1989). A system for multiple integration into these r-DNA units has been developed by Lopes et al. (1989). To select for multi-copy integrants, a selectable marker gene with a partially defective promoter (LEU2-d; Erhart \& Hollenberg 1983) was used. Thus, the leucine-auxotrophic host strain could only be complemented by multiple integration of the expression vector. Selection of transformants on media without leucine yielded integrants carrying 100-200 copies of the expression cassette (Lopes et al. 1989). In shake-flask cultures, multi-copy integrants with the LEU2- $d$ marker were completely stable (Lopes et al. 1989). However, in chemostat experiments, an increase of the leucine concentration in the reservoir medium led to a ten-fold reduction in copy-number of an integrated vector expressing guar $\alpha$-galactosidase (Giuseppin et al. 1993). This indicates that integration of the expression vector is no guarantee for stability under non-selective conditions. When the LEU2-d system is used, the consumption of leucine present in the production media must be prevented. This may be accomplished either by using defined media or by genetically or chemically inhibiting the uptake of this amino acid. The $\delta$-sequences of the retrotransposon Ty occur in a copy number of approximately 80 in the genome ofS. cerevisiae (Cameron et al. 1979) and have been used as a target for integrative recombination of expression vectors.

A multi-copy-integration system targeted to r-DNA sequences is also available for $K$. lactis (Bergkamp et al. 1992, Rossolini et al. 1992) and $K$. marxianus (Bergkamp 1993). In K. lactis, multiple integration in the ribosomal DNA also proved to be very stable in shake-flask cultures: no loss of expression was observed after 70 generations (Bergkamp et al. 1992).

Multiple-integration systems have also been developed for the methylotrophic yeasts Pichia pastoris (Sreekrishna et al. 1989) and Hansenula polymorpha (Roggenkamp et al. 1986). These systems do not rely on targeting of the expression vector to reiterated chromosomal sequences. In P. pastoris, high-copy-number, tandem integration is observed at significant frequencies after transformation with vectors designed for single integration events. Multiple integration of expression vectors in $H$. polymorpha makes use of unstable vectors containing $H$. polymorpha ARS origins of replication. In both yeasts, multi-copy integrants appear to be stable and have been used for the production of heterologous proteins. For more information on these systems, the reader is referred to the review of Romanos et al. (1992).

Because of their high copy number, coupled to a high stability, multicopy integration vectors hold great promise for application in large-scale production of heterologous proteins.

\section{Selection of producing cells}

Marker genes are indispensable for the construction of strains that express heterologous genes. Furthermore, marker genes can be used in the production process to apply a selective pressure against cells that have lost the expression vector. A wide variety of marker genes is currently available for use in $S$. cerevisiae and other yeasts (Reiser et al. 1990, Romanos et al. 1992).

Use of marker genes that encode resistance against antibiotics is generally not desirable in large-scale industrial fermentation. A strong incentive against the use of antibiotics is the price of these compounds. Legal restrictions with respect to the use of antibiotics in the food and pharmaceutical industry also prevent the use of antibiotic-resistance markers.

Use of auxotrophic marker genes to select against cells that have lost the expression cassette is only possible when defined media are used that lack relevant nutrient.

Use of selective media does not guarantee that cells without the expression vector can no longer grow (Mason 1991). In some cases, marker-gene products required for growth can be transferred from mother cells to daughter cells upon cell division. Dilution of essential proteins to below the level that is required for growth may take several generations (Murray \& Szostak 1983; Srienc et al. 1986). Release of marker- 
gene products into the growth medium by cells carrying a marker gene, either by secretion or by lysis, may also sustain growth of non-producing cells (Mason \& Hamer 1987). For example, since $Y$. lipolytica cannot grow on sucrose, the $S$. cerevisiae SUC2 gene encoding invertase can be used as a selectable marker when sucrose (molasses) is used as a carbon source (Nicaud et al. 1989). Dominant marker genes of this type are interesting for large-scale application, since their use does not require the addition of expensive compounds to the production media. However, when invertase is located extracellularly, it will also support growth of cells that have lost the expression vector.

\section{Promoters for the expression of heterologous genes in yeasts}

\section{Constitutive versus inducible promoters}

Many endogenous, foreign and engineered promoters are available for the expression of foreign genes in yeasts. The popularity of tightly regulated, inducible promoters is due to the fact that many of these can support very high expression levels. Furthermore, their inducible nature allows growth and product formation to be separated in time, which is advantageous for production of proteins that are either toxic or instable, and in situations where non-producing variants are selected.

The effect of different induction strategies on productivity is illustrated by numerical simulation (Fig. 3 ). In the reference scenario, production of a heterologous protein is mediated by a constitutive promoter (this regime is identical to the reference simulation shown in Fig. 1). In a second scenario, production of a toxic heterologous protein was induced halfway the process (scenario B). Growth was assumed to cease instantaneously at the onset of product formation. After induction, product formation was assumed to occur at the same rate as in the reference process $\left(q_{p}=2\right.$ $\left.\mathrm{g} \cdot \mathrm{kg}^{-1} \cdot \mathrm{h}^{-1}\right)$. For the sake of comparison, the feed rate was not changed after induction. This led to a dilution of the biomass (Fig. 3) which can be avoided in reallife systems: if biomass formation ceases, there is no need to maintain a high feed rate.

The third scenario (C) shows a fermentation where growth and product formation are separated in a similar way, but formation of the heterologous protein does not have adverse effects on biomass formation (Fig. 3). In this case growth continues after the induction of

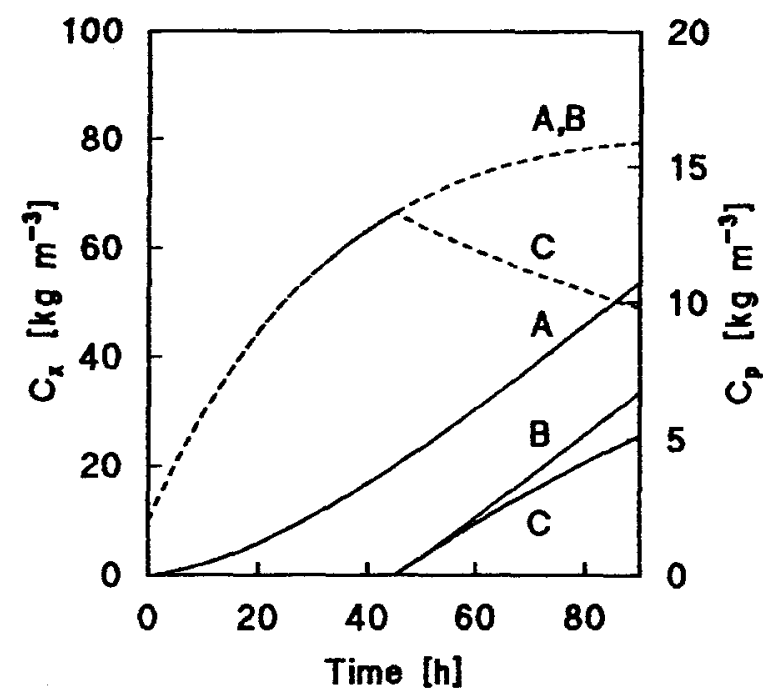

Fig. 3. Effect of different induction strategies on growth and heterologous-protein production in a simulated $100 \mathrm{~m}^{3}$ fed-batch process (process parameters are presented in Table 1). A: Expression of a heterologous gene under the control of a constitutive promoter (as in Fig. 1; reference scenario) B: Expression of a non-toxic heterologous protein under the control of an inducible promoter, which is induced halfway the fermentation (indicated by the arrow) $\mathrm{C}$ : Expression of a toxic heterologous protein that completely inhibits growth, but not product formation, under the control of an inducible promoter. Induction as in scenario B. For the sake of comparison, the simulated feed was continued after induction.

the promoter. Comparison of Figs. $3 \mathrm{~A}$ and $3 \mathrm{C}$ shows that the separation of growth and production phases which is possible when inducible promoters are used, inevitably leads to a loss of productivity compared to a situation where production and growth are coupled throughout the process. Therefore, if there are no compelling reasons (product toxicity, instability of product or expression cassette) to separate biomass and product formation, this should be avoided.

When a switch from the non-producing to the producing (induced or derepressed) state is desired during a large-scale production process, this switch should of course be technically feasible. As will be discussed below, inducible promoter systems that work well in small-scale laboratory environments are not always suitable for application in large-scale processes.

\section{GAL promoters}

Galactose-regulated promoters are probably the most useful promoters for tight control of heterologous-gene expression in $S$. cerevisiae. Under inducing conditions, the enzymes of the Leloir pathway for galactose 
metabolism can account for up to $1.5 \%$ of the total cell protein. GAL promoters are repressed in the presence of glucose, addition of galactose leads to an approximately 1000 -fold induction. The detailed knowledge of the molecular mechanisms responsible for the regulation of $G A L$ promoters has allowed the removal of a number of bottlenecks (Johnston 1987, Fukasawa \& Nogi 1989). For example, the low expression at high copy numbers has been increased by increased levels of the regulatory GALA gene product (Schultz et al. 1987). A drawback of $G A L$ promoters for the large-scale production of low-value proteins may be the high price of galactose. This problem can be circumvented by the use of strains that cannot metabolize galactose and the use of glucose-repression-deficient cells (Hovland et al. 1989). In K. lactis, regulation of both its own and the S. cerevisiae GAL7 promoter appears to be less strict than in $S$. cerevisiae. Even during growth on glucose, relatively high basal expression levels (20\% - 50\% of the induced levels) have been observed (Bergkamp et al. 1992, Rossolini et al. 1992). This makes the GAL7 promoter less suitable for $K$. lactis-based processes in which growth and production have to be strictly separated.

\section{Methanol-induced promoters}

The alcohol-oxidase and formate-dehydrogenase promoters of methylotrophic yeasts can mediate very high expression levels and are tightly regulated. These promoters are induced during growth on methanol and repressed during growth on multi-carbon substrates. Feed regimes in which the relative amounts of these carbon sources are changed during the production process have been successfully applied for the production of a number of heterologous proteins, some of which involved high-cell-density cultures (Brierley et al. 1990, Gellissen et al. 1991). In addition to methanol, also formaldehyde can be used to induce the $H$. polymorpha alcohol-oxidase promoter (Veale et al. 1992, Giuseppin et al. 1993). However, in view of its toxicity, induction with formaldehyde is not compatible with large-scale processes.

In wild-type methylotrophic yeasts, induction of the alcohol-oxidase promoter results in the formation of large amounts of methanol oxidase protein. In $P$. pastoris, mutants have been constructed which do not produce the AOXI gene product (Cregg et al. 1987). Slow growth on methanol is still possible because of the synthesis of low levels of a second alcohol oxidase, encoded by the $A O X 2$ gene. The advantage of this phe- notype is that more metabolic energy and carbon can be directed to the synthesis of heterologous proteins.

\section{Temperature-regulated promoters}

Some promoters for use in S. cerevisiae can be induced by a temperature down-shift from 37 to $24^{\circ} \mathrm{C}$ (Brake et al. 1984, Kramer et al. 1984, Sledziewski et al. 1988, Walton \& Yarranton 1989). Large-scale fermentations are operated at maximum cooling capacity. If induction of heterologous-gene expression by a temperature down-shift in a large-scale process is required, this can only be achieved if a decrease of the heat production is realized, e.g. by lowering the feed rate. Thus, a temperature down-shift inevitably causes a decrease in productivity.

Yeast promoters inducible by a temperature upshift (DaSilva \& Bailey 1989, Kirk \& Piper 1991) offer a more realistic option for inducible expression in large-scale processes. A temperature increase can be achieved in a short period. For example, when a bioreactor is operating at a maximum oxygen-transfer capacity (around $100 \mathrm{~mol} \cdot \mathrm{m}^{-3} \cdot \mathrm{h}^{-1}$; Van 't Riet 1983), $45.5 \cdot 10^{3} \mathrm{~kJ} \cdot \mathrm{h}^{-1}$ are released as heat. In a closed system, this corresponds to a temperature increase of 3.2 $\mathrm{K} \cdot \mathrm{min}^{-1}$.

\section{Phosphate-regulated promoters}

Wild-type and engineered S. cerevisiae PHOS promoters are repressed by inorganic phosphate (Hinnen et al. 1989). In large-scale fermentations, it is not feasible to replace the culture medium. Consequently, phosphate limitation has to be achieved by lowering the supply rate of this nutrient. This is difficult to accomplish in complex media. When defined media are used, phosphate limitation can be imposed by switching to a medium without phosphate. However, when $S$. cerevisiae is grown on sugar substrates, growth limitations other than the sugar itself trigger alcoholic fermentation. Also in other yeasts, metabolite formation increases dramatically when growth is not carbon-limited (Hensing \& van Dijken, unpublished). Furthermore, when growth is not carbon-limited, assimilation and dissimilation may become uncoupled, leading to lower biomass yields and consequently to a lower productivity. These problems severely limit the applicability of PHO5-derived promoters. 


\section{Glucose-repressible promoters}

A number of $S$. cerevisiae promoters, including $A D H 2$, $S U C 2$ and $C Y C 1$ are repressed by excess sugar. Derepression can be achieved by changing the substrate from sugar to, e.g., glycerol or ethanol. Repression of these promoters by growth on excess sugar cannot be achieved in large-scale fermentations of Crabtree-positive yeasts, which have to be strictly sugar-limited to avoid alcoholic fermentation. The low residual-sugar concentrations in such processes will already lead to a partial derepression of glucoserepressible promoters. For example, the Schizosaccharomyces pombe FBP (fructose bisphosphatase) promoter is already derepressed at glucose concentrations of $1 \mathrm{~g} \cdot 1^{-1}$ (Hoffman \& Winston 1989). Therefore, glucose-repressed promoters are of limited use when growth and product formation have to be strictly separated.

\section{Influence of physiological parameters on heterologous-protein production}

\section{Metabolite production}

Large-scale fed-batch processes for the production of heterologous proteins are in principle aerobic and sugar-limited. However, during large-scale cultivation of yeasts at high biomass densities, it is virtually impossible to avoid local gradients in sugar- and oxygen concentration. These may have a profound effect on the occurrence of alcoholic fermentation. Production of ethanol and other metabolites causes a diversion of substrate carbon from biomass and protein production and is therefore not desired. Furthermore, the energetic efficiency of alcoholic fermentation is much lower than that of respiratory sugar metabolism, which augments the negative effect on biomass and protein yields.

Yeasts can be divided in two groups, based on their tendency to perform alcoholic fermentation under aerobic conditions. The so-called Crabtree-positive yeasts exhibit alcoholic fermentation under aerobic conditions, unless the sugar-supply rate is low and growthlimiting (de Deken 1966, Petrik et al. 1983, Van Urk et al. 1990). In Crabtree-positive yeasts, exposure of aerobic, sugar-limited cultures to excess sugar leads to instantaneous ethanol formation. In $S$. cerevisiae, this fermentative response already occurs at glucose concentrations of $0.15 \mathrm{~g} \cdot 1^{-1}$ (Fig. 4). In Crabtree-negative yeasts, on the other hand, aerobic ethanol formation

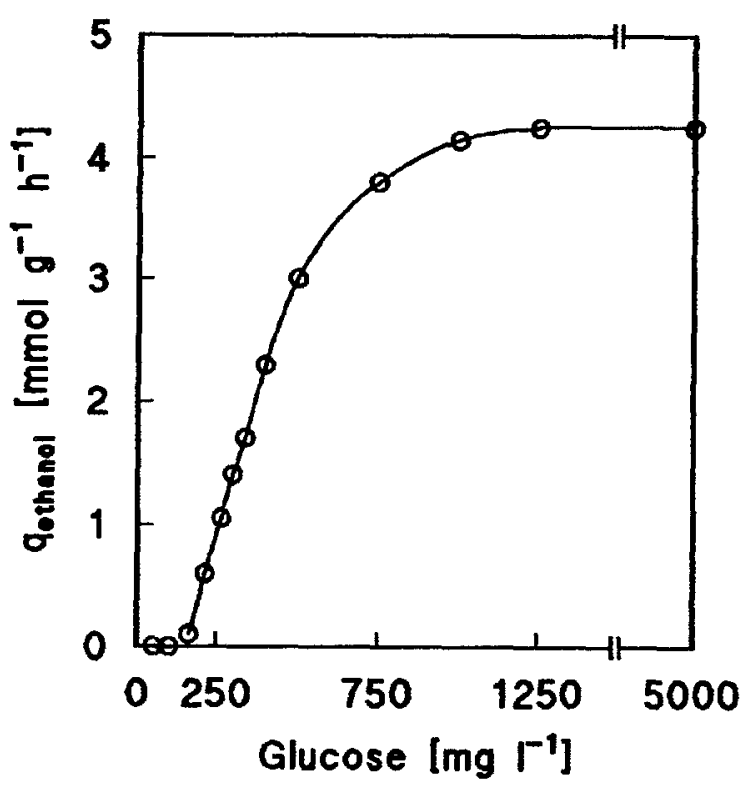

Fig. 4. Rates of ethanol production upon addition of various concentrations of glucose to aerobic cell suspensions of Saccharomyces cerevisiae. Data from Verduyn et al. (1984).

does not occur. However, also in Crabtree-negative yeasts, alcoholic fermentation is rapidly induced when growth becomes oxygen-limited.

Ethanol production is almost invariably accompanied by the production of other metabolites, including weak organic acids (Postma et al. 1989). Since yeasts are normally grown at acidic $\mathrm{pH}$ values, weak organic acids dissipate the trans-membrane $\mathrm{pH}$ gradient across the plasma membrane (Alexander et al. 1987, Verduyn et al. 1992). To maintain a near-neutral intracellular $\mathrm{pH}$, protons have to be expelled from the cell by the plasma-membrane ATPase complex. The ATP required for this process is provided by the dissimilation of glucose, thereby causing a decrease of the biomass and protein yield (Verduyn et al. 1992).

The division of yeasts in Crabtree-positive and Crabtree-negative species is based on experimental data obtained in low-cell-density, laboratory-scale cultures. These data cannot always be extrapolated to large-scale, high-cell-density cultures. In some Crabtree-negative yeasts, very low specific production rates of metabolites (e.g. organic acids) occur in aerobic, sugar-limited cultures grown at low cell densities $\left(<5 \mathrm{~g} \cdot \mathrm{l}^{-1}\right)$. Under such conditions, the resulting metabolite concentrations are often so low that they go unnoticed. However, at high cell densities, the concentration in the culture fluid may become suffi- 
ciently high to cause deleterious effects. Therefore, an apparent Crabtree-negative phenotype in low-celldensity, laboratory-scale fermentations is not a guarantee that metabolite formation will not be a problem under industrial conditions.

In large-scale fermentations, the high hydrostatic pressures in the lower parts of the reactors may lead to high dissolved- $\mathrm{CO}_{2}$ concentrations. Although high concentrations of carbon dioxide and/or bicarbonate negatively affect some enzyme activities, there are as yet no clear indications that toxic effects of carbon dioxide affect normally operated batch fermentations (Onken \& Liefke 1989). In a study on fed-batch cultures of Saccharomyces cerevisiae (Chen \& Gutmanis 1976), negative effects on biomass formation were only observed at $\mathrm{CO}_{2}$ pressures above $350 \mathrm{mbar}(1 \mathrm{bar}$ air pressure corresponds to $0.35 \mathrm{mbar} \mathrm{CO}_{2}$ ). Nevertheless, and especially at high cell densities, the possibility of $\mathrm{CO}_{2}$ toxicity cannot a priori be ruled out.

\section{Maintenance-energy requirements}

Since the advent of techniques for the continuous cultivation of microorganisms, it has become clear that the biomass yield on the growth-limiting substrate $\left(\mathrm{Y}_{s x}\right)$ is not independent of the specific growth rate $(\mu)$. According to the maintenance-energy concept (Pirt 1965, Stouthamer \& Bettenhausen 1973), part of the metabolic energy generated during catabolism is not directly used for biomass formation. Instead, this socalled maintenance energy is used for various nongrowth-associated processes such as $\mathrm{pH}$ homeostasis, turnover of macromolecules, kinetic proof-reading at the ribosomes and futile cycles.

In the original (and still most commonly used) model to describe the effects of maintenance-energy requirement on the physiology, it is assumed that maintenance-energy requirements are growth-rate independent. Based on this assumption, the biomass yield on substrate can be described by the equation $\left(\mathrm{Y}_{s x}\right)^{-1}=\left(\mathrm{Y}_{s x}^{\max }\right)^{-1}+\mathrm{m}_{s} \cdot \mu^{-1}$, in which $\mathrm{Y}_{s x}$ is the observed molar growth yield, $\mathrm{Y}_{s x} \max$ is the 'true' molar growth yield corrected for maintenance requirements, $\mu$ is the specific growth rate and $\mathrm{m}_{s}$ the maintenance coefficient $(\mathrm{kg}$ substrate $(\mathrm{kg}$ biomass) $^{-1} \cdot \mathrm{h}^{-1}$ ).

High maintenance requirements go at the expense of biomass and product formation (van Verseveld et al. 1986, Stouthamer \& van Verseveld 1987, de Hollander 1993) and are therefore not desired in heterologous protein production. To illustrate the effect of maintenance-
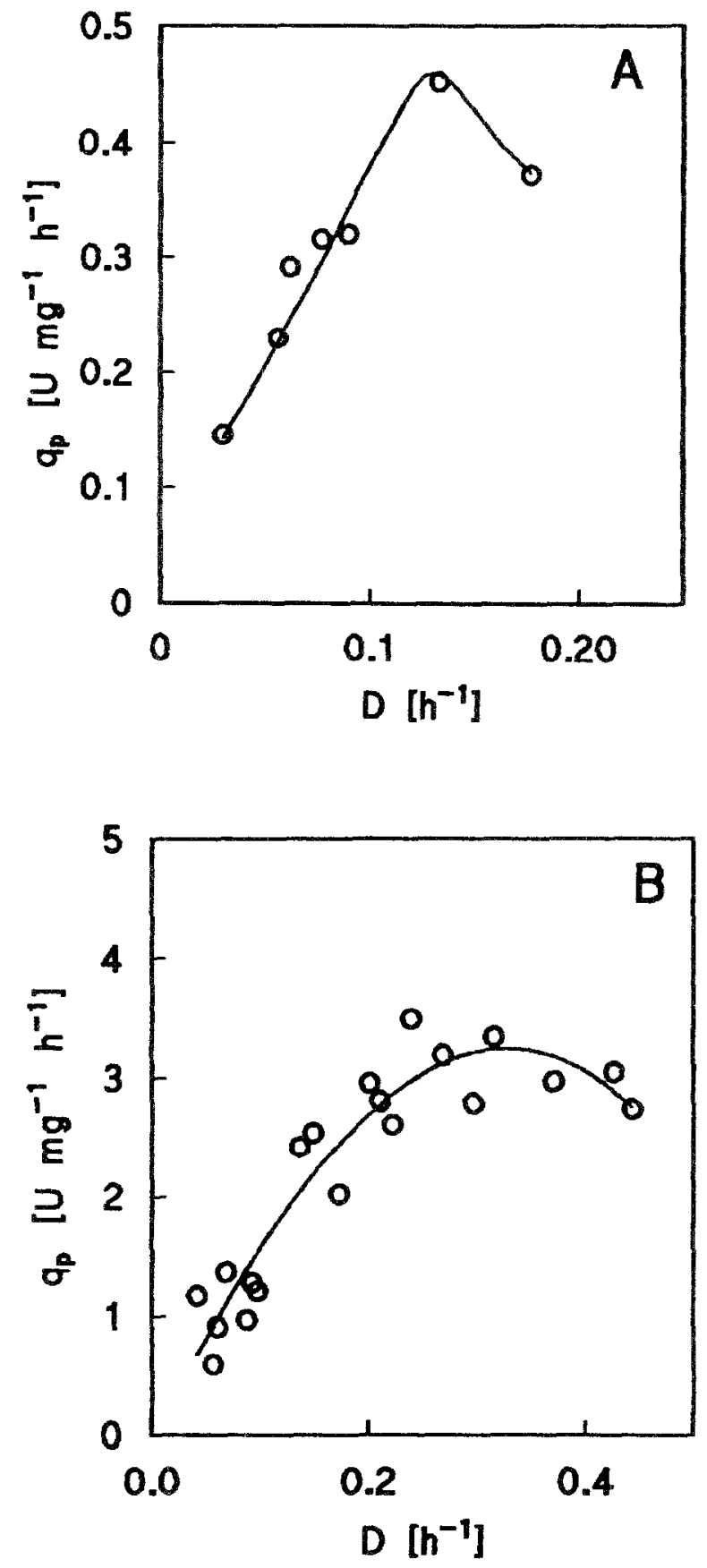

Fig. 5. Relation between growth rate and specific product-formation rate of two homologous proteins produced by yeasts. A. Production of intracellular alcohol oxidase by Hansenula polymorpha, grown in methanol-limited chemostat cultures. Data from van Dijken et al. (1976). B. Production of extracellular inulinase by Kluyveromyces marxianus in sucrose-limited chemostat cultures. Data from Hensing et al. (unpublished). 
Table 4. Simulated effects of maintenance requirements on final product yield, biomass yield and fraction of substrate used for maintenance purposes in a large-scale fed-batch process for heterologous-protein production. Only the maintenance coefficient $\left(\mathrm{m}_{s}\right)$ was varied in the simulated process, other process parameters were as shown in Table 3 . In all cases, the total amount of glucose fed to the process was $25011 \mathrm{~kg}$.

\begin{tabular}{llll}
\hline $\begin{array}{l}\mathrm{m}_{\text {s }} \text { kg glucose. } \\
(\mathrm{kg} \text { biomass })^{-1} \cdot \mathrm{h}^{-1}\end{array}$ & $\begin{array}{l}\text { Biomass produced } \\
(\mathrm{kg})\end{array}$ & $\begin{array}{l}\text { Heterologous protein } \\
\text { produced }(\mathrm{kg})\end{array}$ & $\begin{array}{l}\text { Fraction of substrate } \\
\text { used for maintenance (\%) }\end{array}$ \\
\hline 0.020 & 8072 & 1126 & 35.5 \\
$0.024^{1}$ & 7452 & 1073 & 40.4 \\
0.030 & 6642 & 1000 & 46.9 \\
0.040 & 5548 & 896 & 55.6 \\
\hline
\end{tabular}

${ }^{1}$ Reference scenario, see Table 3 and Fig. 1.

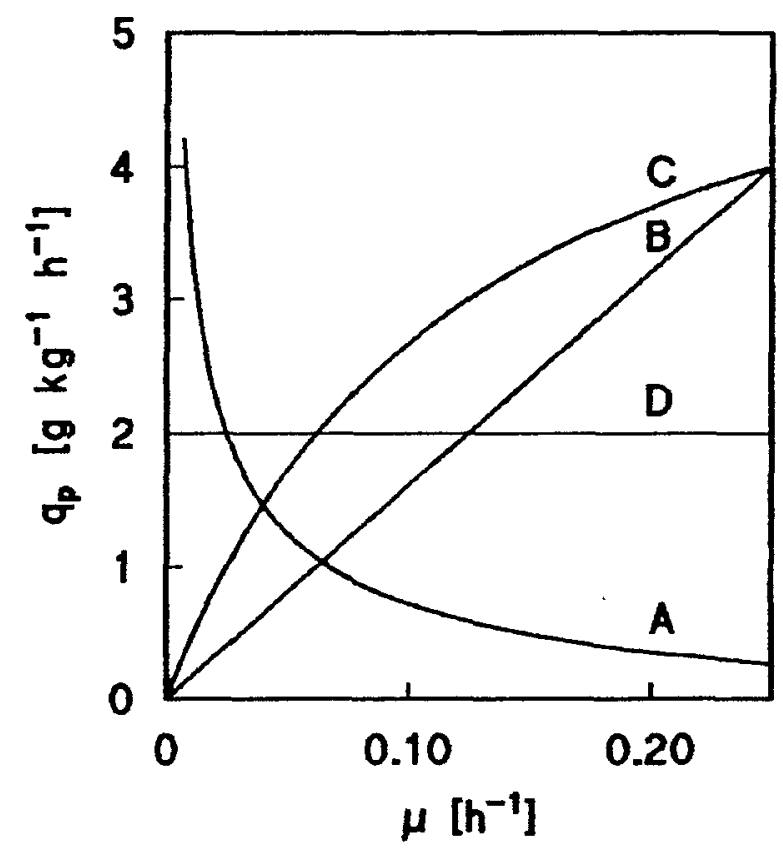

Fig. 6. Theoretical relationships between specific growth rate $(\mu)$ and specific product-formation rate $\left(\mathrm{q}_{p}\right)$ in microorganisms, according to Terwisscha van Scheltinga (1990). A. Repressed or maintenance-coupled production, B. Growth-coupled production, C. Saturated production, D. Growth-rate-independent production. Mathematical descriptions of the profiles shown in this Fig. are given in Appendix 1.

energy requirements on the large-scale production of heterologous proteins in yeasts, we introduced different values for $\mathrm{m}_{s}$ in the simulated process. These simulations indicate that changes in the maintenanceenergy requirement may have a substantial impact on overall productivity (Table 4 ). For example, when $\mathrm{m}_{s}$ is increased from 0.024 to $0.040 \mathrm{~kg} \cdot \mathrm{kg}^{-1} \cdot \mathrm{h}^{-1}$, this results in a $16.5 \%$ decrease of the predicted protein production.

Maintenance requirements of yeasts may be significantly influenced by environmental parameters, including temperature, $\mathrm{pH}$, medium composition and presence of uncoupling metabolites (for a review see Verduyn 1991). The simulation data presented in Table 4 indicate that the maintenance-energy requirement is a key factor in the choice of host organism and growth conditions for heterologous-protein production.

\section{Effect of growth rate on product formation}

In the simulations presented in the Figs. 1-3 and Table 4 it was assumed that the specific rate of product formation $\left(\mathrm{q}_{p}\right)$ is independent of the specific growth rate $(\mu)$. However, this assumption is not necessarily correct. In fact, production rates of many homologous proteins change as a function of $\mu$ (Fig. 5). Since a continuously decreasing growth rate is a common characteristic of large-scale fed-batch processes, it is of key importance to know the relationship between $\mu$ and $\mathrm{q}_{p}$.

The expression of many genes is regulated primarily at the level of transcription. When expression of a heterologous protein is mediated by a homologous promoter, relevant information may be obtained by studying the regulation of the homologous gene under the control of that promoter. Such studies can only be useful when the expression cassette is present at a low copy number. In high-copy situations, factors other than the initiation of transcription may become rate limiting and determine the $\mu$ versus $\mathrm{q}_{p}$ relationship. In some cases, the presence of down-stream activating sequences may also reduce the applicability of promoter studies in homologous systems. 
As mentioned above, continuous cultivation offers a very useful tool for the determination of $\mathrm{q}_{p}$. Since prolonged continuous cultivation requires an almost absolute stability of the expression system, these studies are very difficult to perform with episomal expression vectors. Indeed, only with the recent development of stable multi-copy integrating vectors, studies into the effect of growth rate on heterologous-gene expression in multi-copy systems have been reported in the literature (Giuseppin et al. 1993).

The $\mathrm{D}-\mathrm{q}_{p}$ relationship measured in continuous cultures is not necessarily identical to the $\mu-\mathrm{q}_{p}$ pattern observed in fed-batch cultures. A key factor in this respect is that, in continuous cultures, $\mathrm{q}_{p}$ is measured in steady-state situations, whereas in fed-batch cultures, steady-state conditions do not exist due to the constantly decreasing growth rates. The extent to which $\mu-\mathrm{q}_{p}$ in the two systems are comparable depends on the relaxation time (Roels 1983) of the regulation of heterologous gene expression.

Four patterns of $\mu-q_{p}$ relationships can be envisaged (Fig. 6; Terwisscha van Scheltinga 1990). In repressed or maintenance-coupled production profiles, $\mathrm{q}_{p}$ increases with decreasing growth rate. In the case of growth-coupled production, $\mathrm{q}_{p}$ increases linearly with increasing $\mu$. An increase of $\mathrm{q}_{p}$ with increasing $\mu$ is also observed in the case of saturated production kinetics. However, in this case the increase of $q_{p}$ levels off at high growth rates (the relationship between $\mu$ and $\mathrm{q}_{p}$ can often be described by Michaelis-Mententype equations). Growth-rate-independent production represents the simplest $\mu-\mathrm{q}_{p}$ relation, which has been used for the simulations presented in Figs. 1-3 and Table 4.

In view of the decreasing growth rate and increasing biomass concentration in fed-batch processes, a high $\mathrm{q}_{p}$ at low specific growth rates is clearly desirable. This is illustrated by the simulated fed-batch processes shown in Fig. 7: maintenance-coupled and growth-rate-independent profiles result in the highest productivity. In practice however, growth-coupled or saturated production kinetics are often observed (see e.g. Fig. 5).

When the relationship between $\mu$ and $\mathrm{q}_{p}$ is known, this allows the calculation of the optimum growth-rate trajectory in the industrial fed-batch process (Heijnen et al. 1979, de Hollander 1993). Both the specific rate of biomass formation $(\mu)$ and that of protein production $\left(q_{p}\right)$ affect the overall productivity. Therefore, maximum overall productivity is not necessarily obtained at

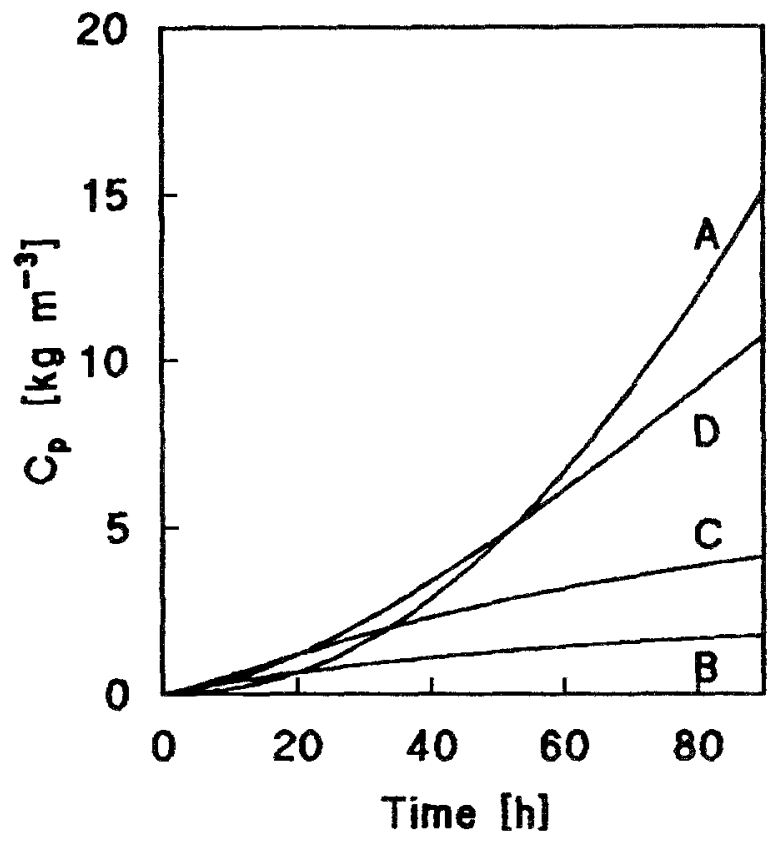

Fig. 7. Effect of $\mu$ versus $\mathrm{q}_{p}$ relationships on simulated heterologous-protein production in a $100 \mathrm{~m}^{3}$ fed-batch process. For the simulation, the $\mu-q_{p}$ relationships presented in Fig. 5 were entered in the PSI-c simulation program presented in Appendix 1. Mathematical descriptions of the $\mu-q_{p}$ relationships used in the simulation are also given in Appendix 1. Other process parameters are presented in Table 1. A, Repressed or maintenance-coupled production; B, Growth-coupled production; C, Saturated production; D, Growth-rate-independent production $\left(\mathrm{q}_{p}=2 \mathrm{~g} \cdot \mathrm{kg} \cdot \mathrm{h}^{-1}\right.$; reference scenario).

the growth rate at which $\mathrm{q}_{p}$ is maximal (de Hollander 1993).

To our knowledge, the only quantitative data on $\mu-\mathrm{q}_{p}$ relationships for heterologous-protein production by yeasts have been reported by Giuseppin et al. (1993). Production of heterologous $\alpha$-galactosidase was studied in chemostat cultures of $S$. cerevisiae and $H$. polymorpha. Both strains carried integrated expression cassettes under the control of the GAL7 and $M O X 1$ promoter, respectively. In $S$. cerevisiae grown on mixtures of glucose and galactose, $q_{p}$ increased with increasing dilution rate up to $\mathrm{D}=0.2 \mathrm{~h}^{-1}$, where $\mathrm{q}_{p}$ reached a maximum of approximately $4.5 \mathrm{~g} \cdot \mathrm{kg}^{-1} \cdot \mathrm{h}^{-1}$. At the lowest dilution rate tested $\left(0.05 \mathrm{~h}^{-1}\right), \mathrm{q}_{p}$ was still around $3 \mathrm{~g} \cdot \mathrm{kg}^{-1} \cdot \mathrm{h}^{-1}$. In $H$. polymorpha grown on mixtures of glucose and formaldehyde, a peculiar two-peaked $\mu$ versus $q_{p}$ profile was found, with a maximum $\mathrm{q}_{p}$ of as high as $5.5 \mathrm{~g} \cdot \mathrm{kg}^{-1} \cdot \mathrm{h}^{-1}$ at $\mathrm{D}=0.08 \mathrm{~h}^{-1}$ and at $D=0.18 \mathrm{~h}^{-1}$, which mirrored the production 
of the homologous protein alcohol oxidase. When the dilution rate was lowered from $0.08 \mathrm{~h}^{-1}$ to $0.05 \mathrm{~h}^{-1}$, $\mathrm{q}_{p}$ decreased to around $1.6 \mathrm{~g} \cdot \mathrm{kg}^{-1} \cdot \mathrm{h}^{-1}$. Further studies of this type are required to determine to what extent $\mu$ versus $\mathrm{q}_{p}$ patterns can be optimized by genetic, physiological or technological modification of heterologous protein production.

\section{Concluding remarks}

In the past decade molecular genetics has laid the foundations for the commercial exploitation of yeasts for the production of heterologous proteins. However, fundamental knowledge with respect to physiology and fermentation technology of genetically modified yeast is scarcely available in the scientific literature. From a process point of view, the concerted action of geneticists, physiologists and process engineers is a necessity to achieve the required scaling-up of culture volume by six orders of magnitude. In this review, we have attempted to illustrate this by discussing largescale processes for the production of heterologous proteins in fed-batch cultures. Since this cultivation method involves high cell densities and a low average growth rate, studies on gene expression should take into account the specific production rate of the protein of interest (amount of product per unit biomass and per unit of time), and in particular its relation to the specific growth rate. The numerous physiological and technological restraints on large-scale fermentation processes should, at an early stage, be taken into account in research on the expression of heterologous genes in yeasts.

\section{Acknowledgements}

We thank Dr. Wouter Musters and Dr. Yde Steensma for critical reading of the manuscript. This work was sponsored by the Dutch Ministry of Economic Affairs and by Unilever Research Vlaardingen.

\section{Appendix 1.}

PSI c program for the simulation of large-scale fermentations.

$\begin{array}{lll}\text { Parameter } & \text { Symbol } & \text { PSI c algorithm } \\ \text { Biomass concentration } & \mathrm{C}_{x} & \operatorname{int}\left(\mathrm{dC}_{x} \mathrm{dt} \text { par: } \mathrm{C}_{x o}\right) \\ \text { Volume } & \mathrm{V} & \operatorname{int}\left(\mathrm{F} \text { par: } \mathrm{V}_{o}\right)\end{array}$

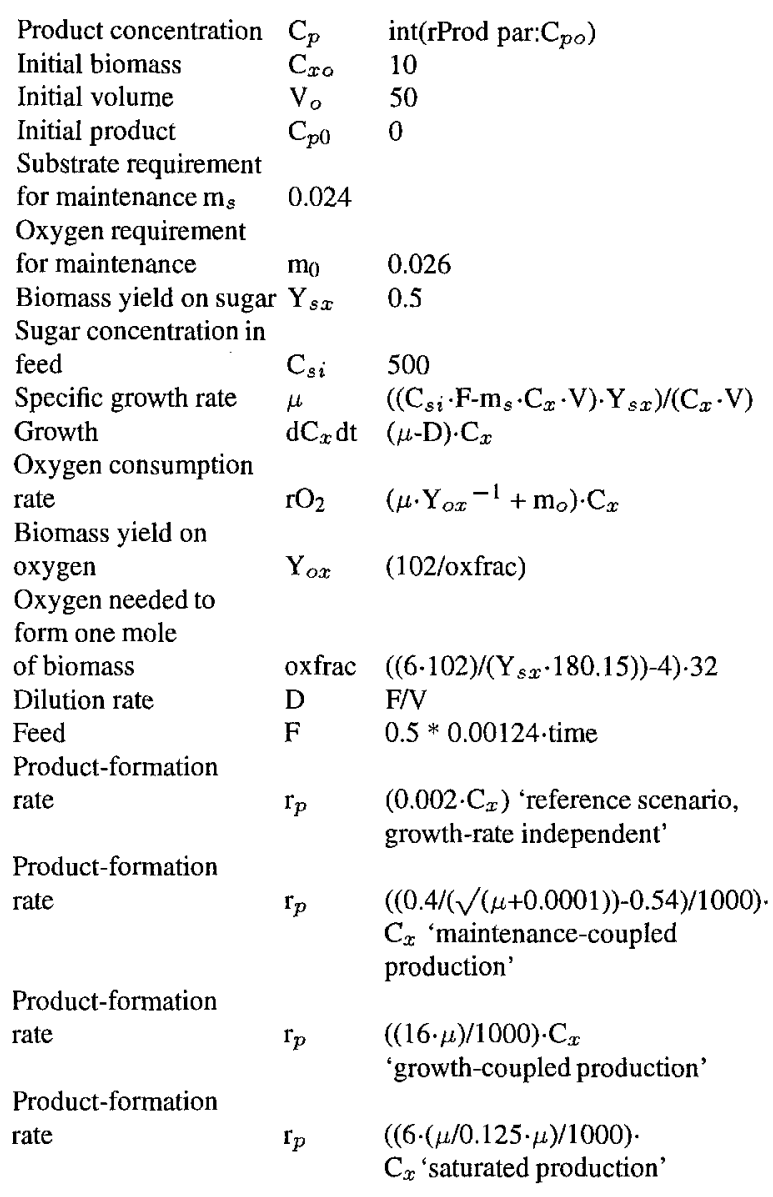

\section{References}

Alberghina L, Porro D, Martegani E \& Ranzi BM (1991) Efficient production of recombinant DNA proteins in Saccharomycescerevisiae by controlled high-cell-density fermentation. Biotechnol. Appl. Biochem. 14: 82-92

Alexander B, Leach S \& Ingledew WJ (1987) The relationship between chemiosmotic parameters and sensitivity to anions and organic acids in the acidophile Thiobacillus ferrooxidans. J. Gen. Microbiol. 133: 1171-1179

Arbige MV \& Pitcher WH (1989) Industrial enzymology: a look towards the future. Trends Biotechnol. 7: 330-335

Beggs JD, van der Berg J, van Ooyen A \& Weissman C (1980) Abnormal expression of chromosomal rabbit B-globin in Saccharomyces cerevisiae. Nature 283: 835-840

Bergkamp RJM, Kool IM, Geerse RH \& Planta RJ (1992) Multiplecopy integration of the $\alpha$-galactosidase gene from Cyamopsis tetragonoloba into the ribosomal DNA of Kluyveromyces lactis. Curr. Genet. 21: 365-370

Bergkamp RJM (1993) Heterologous gene expression in Kluyveromyces yeasts. $\mathrm{PhD}$ Thesis, University of Amsterdam, The Netherlands

Beudeker RF, van Dam HW, van der Plaat JB \& Vellenga K (1990) Developments in bakers' yeast production. In: Verachtert $H \&$ de 
Mot R (Eds) Yeast Biotechnology and Biocatalysis (pp. 103-145. Marcel Dekker Inc., New York

Bianchi MM, Santarelli R \& Frontali L (1991) Plasmid functions involved in the stable propagation of the $\mathrm{pKD} 1$ circular plasmid in Kluyveromyces lactis. Curr. Genet. 19: 155-161

Bijvoet JFM, van der Zanden AL, Goosen N, Brouwer J \& van de Putte P (1991) DNA insertions in the silent regions of the $2 \mu \mathrm{m}$ plasmid of Saccharomyces cerevisiae influence plasmid stability. Yeast 7: 347-356

Brake AJ, Merryweather JP, Coit DG, Heberlein UA, Masiarz FR, Mullenbach GT, Urdea MS, Valenzuela P \& Barr PJ (1984) $\alpha$ factor-directed synthesis and secretion of mature foreign proteins in Saccharomyces cerevisiae. Proc. Natl. Acad. Sci. USA 81: $4642-4646$

Brierley RA, Siegel RS, Bussineau CM, Craig WS, Holtz GC, Davis GR,Buckholz RG, Thill GP, Wondrack LM, Digan ME, Harpold MM, Lair SV, Ellis SB \& Williams ME (1990) Mixed feed recombinant yeast fermentation. W.O. Patent 90/03431

Buckholz RG \& Gleeson MAG (1991) Yeast sytems for the commercial production of heterologous proteins. Bio/Technology 9: 1067-1072

Cameron JR, Loh EY \& Davis RW (1979) Evidence for transposition of dispersed repetitive DNA families in yeast. Cell 16: 739-751

Chen SL \& Gutmanis F (1976) Carbon dioxide inhibition of yeast growth in biomass production. Biotechnol. Bioeng. 18: 14551462

Cheng SC \& Ogrydziak DM (1986) Extracellular RNase produced by Yarrowia lipolytica. J. Bacteriol. 168: 581-589

Clare JJ, Rayment FB, Ballantine SP, Sreekrishna K \& Romanos MA (1991a) High-level expression of tetanus toxin fragment $\mathrm{c}$ in Pichia pastoris strains containing multiple tandem integrations of the gene. Bio/Technology 9: 455-460

Clare JJ, Romanos MA, Rayment FB, Rowedder JE, Smith MA, Payne MM, Sreekrish- na K \& Henwood CA (1991b) Production of mouse epidermal growth factor in yeast: high-level secretion using Pichia pastoris strains containing multiple gene copies. Gene 105: 205-212

Couderc R \& Barratti J (1980) Oxidation of methanol by the yeast Pichia pastoris. Purification and properties of alcohol oxidase. Agric. Biol. Chem. 44: 2279-2289

Cregg JM, Tschopp JF, Stillman C, Siegel R, Akong M, Craig WS, Buckholz RG, Madden KR, Kellaris PA, Davis GR, Smiley BL, Cruze J, Torregrossa R, Veliçelebi G \& Thill GP (1987) High-level expression and efficient assembly of hepatitis B surface antigen in the methylotrophic yeast Pichia pastoris. Bio/Technology 5: 479-485

DaSilva NA \& Bailey JE (1989) Construction and characterization of a temperature-sensitive expression system in yeast. Biotech. Prog. 5: 18-26

De Deken RH (1966) The Crabtree effect: a regulatory system in yeast. J. Gen. Microbiol, 44: 149-156

De Hollander JA (1993) Kinetics of microbial product formation and its consequences for the optimization of fermentation processes. Antonie van Leeuwenhoek 63: 375-381

Diers I (1976) Glucose isomerase in Bacillus coagulans. In: Dean ACR, Ellwood DC, Evans CGT \& Melling J (Eds) Continuous Culture 6: Applications and New Fields (pp. 208-225)Ellis Horwood, Chichester

Digan ME, Lair SV, Brierley RA, Siegel RS, Williams ME, Ellis SB, Kellaris PA, Provow SA, Craig WS, Veliçelebi G, Harpold MM \& Thill GP (1989) Continuous production of a novel lysozyme via secretion from the yeast, Pichia pastoris. Bio/Technology 7 : $160-164$
Ellis SB, Brust PF, Koutz PJ, Waters AF, Harpold MM \& Gingeras TR (1985) Isolation of alcohol oxidase and two other methanol regulatable genes from the yeast Pichia pastoris. Mol. Cell. Biol. 5: $1111-1121$

Erhart E \& Hollenberg CP (1983) The presence of a defective LEU2 gene on $2 \mu \mathrm{m}$ DNA recombinant plasmids of Saccharomyces cerevisiae is responsible for curing and high copy number. J. Bacteriol. 156: 625-635

Falcone C, Saliola M, Chen XJ, Frontali L \& Fukuhara $H$ (1986) Analysis of a $1.6 \mu \mathrm{m}$ circular plasmid from the yeast Kluyveromyces drosophilarum: structure and molecular dimorphism. Plasmid 15: 248-252

Fiechter A, Fuhrmann GF \& Käppeli O (1981) Regulation of glucose metabolism in growing yeast cells. Adv. Microb. Physiol. 22: 123-183

Fieschko JC, Egan KM, Ritch T, Koski RA, Jones M \& Bitter GA (1987) Controlled expression and purification of human immune interferon from high-cell-density fermentations of Saccharomyces cerevisiae. Biotechnol. Bioeng. 29: 1113-1121

Fleer R, Yeh P, Amellal N, Maury I, Fournier A, Bacchetta F, Baduel P, Jung G, L'Hôte H, Becquart J, Fukuhara H \& Mayaux JF (1991) Stable multicopy vectors for high-level secretion of recombinant human serum albumin by Kluyveromyces yeasts. Bio/technology 9: 968-975

Fukasawa T \& Nogi Y (1989) Molecular genetics of galactose metabolism in yeast. In: Barr PJ Brake AJ \& Valenzuela P (Eds) Yeast genetic Engineering (pp. 1-18) Butterworths, Stoneham

Futcher AB (1988) The $2 \mu \mathrm{m}$ circle plasmid of Saccharomyces cerevisiae. Yeast 4: 27-40

Futcher AB \& Cox BS (1984) Copy number and stability of $2 \mu \mathrm{m}$ circle-based artificial plasmids of Saccharomyces cerevisiae. J. Bacteriol. 157: 283-290

Gellissen G, Janowicz ZA, Merckelbach A, Piontek M, Keup P, Weydemann U, Hollenberg CP \& Strasser AWM (1991) Heterologous gene expression in Hansenula polymorpha: efficient secretion of glucoamylase. Bio/technol, 9: 291-295

Gellissen G, Melber K, Janowicz ZA, Dahlems UM, Weydemann U, Pointek M, Strasser AWM \& Hollenberg CP (1992) Heterologous protein production in yeast. Antonie van Leeuwenhoek 62: 79-93

Giuseppin MLF, van Eijk HMJ, Bos A, Verduyn C \& van Dijken JP (1988) Utilization of methanol in a catalase-negative mutant of Hansenula polymorpha. Appl. Microbiol. Biotechnol. 28: 286 292

Giuseppin MLF, Almkerk JW, Heistek JC \& Verrips CT (1993) Comparative study on the production of guar $\alpha$-galactosidase by Saccharomyces cerevisiae SU50B and Hansenula polymorpha $8 / 2$ in continuous culture. Appl. Environ. Microbiol. 59: 52-59

Goodey AR (1993) The production of heterologous plasma proteins. Trends Biotechnol. 11:430-433

Graefe G (1975) Zucker und Zuckeralkohole. Starch 5: 160-169

Gu MB, Park MH \& Kim DI (1991) Growth rate control in fedbatch cultures of recombinant Saccharomyces cerevisiae producing hepatitis B surface antigen (HBsAg). Appl. Microbiol. Biotechnol. 35: 46-50

Hacking AJ (1986) Economic aspects of biotechnology. Cambridge University Press, Cambridge

Hagenson MJ, Holden KA, Parker KA, Wood PJ, Cruze JA, Fuke M, Hopkins TR \& Stroman DW (1989) Expression of streptokinase in Pichia pastoris yeast. Enzyme Microb. Technol, 11:650-656

Heinisch JJ \& Hollenberg CA (1993) Yeast. In: Sahm H (Ed) Biotechnology Vol. 1 (pp. 469-514) VCH, Weinheim

Heijnen JJ, Roels JA \& Stouthamer AH (1979) Application of balancing methods in modeling the penicillin fermentation. Biotechnol. Bioeng. 21: 2175-201 
Heijnen JJ, Terwisscha van Scheltinga AH \& Straathof AJ (1992) Fundamental bottlenecks in the application of continuous bioprocesses. J. Biotechnol. 22: 3-20

Heslot H (1990) Genetics and genetic engineering of the industrial yeast Yarrowia lipolytica. Adv. Biochem. Eng. Biotechnol. 43: 43-71

Hinnen A, Meyhack B \& Heim J (1989) Heterologous gene expression in yeast. In: Barr PJ, Brake AJ \& Valenzuela P (Eds) Yeast genetic engineering (pp. 193-213) Butterworths, Stoneham

Hodgkins M, Mead D, Ballance DJ, Goodey A and Sudbery P (1993) Expression of the glucose oxidase gene from Aspergillus niger in Hansenula polymorpha and its use as a reporter gene to isolate regulatory mutations. Yeast 9:625-635

Hoffman CS \& Winston F (1989) A transcriptionally regulated expression vector for the fission yeast Schizosaccharomyces pombe. Gene 84: 473-479

Hough JS, Keevil CW, Maric V, Philliskirk G \& Young TW (1976) Continuous culture in brewing. In: Dean ACR, Ellwood DC, Evans CGT \& Melling J (Eds) Continuous culture 6: Applications and new fields (pp. 226-237) Ellis Horwood, Chicester

Hovland P, Flick J, Johnston M \& Sclafani RA (1989) Galactose as a gratuitous inducer of $G A L$ gene expression in yeasts growing in glucose. Gene 83: 57-64

Janowicz ZA, Merckelbach A, Eckart M, Weydmann U, Roggenkamp R \& Hollenberg CP (1988) Expression system based on the methylotrophic yeast Hansenula polymorpha. Yeast 4: $\$ 155$

Johnston M (1987) A model fungal gene regulatory mechanism: the GAL genes of Saccharomycescerevisiae. Microbiol. Rev. 51: $458-476$

Kirk, N \& Piper PW (1991) The determinants of heat-shock-elementdirected lacZ expression in Saccharomyces cerevisiae. Yeast 7: 539-541

Kramer RA, DeChiara TM, Schaber MD \& Hilliker S (1984) Regulated expression of a human interferon gene in yeast: control by phosphate concentration or temperature. Proc. Natl. Acad. Sci. USA $81: 367-370$

Ledeboer AM, Edens L, Maat $\mathbf{J}$, Visser C, Bos JW, Verrips CT, Janowicz ZA, Eckart M, RoggenkampR \& Hollenberg CP (1985) Molecular cloning and characterisation of a gene coding for methanol oxidase in Hansenula polymorpha. Nucl. Acids Res. 13: 3063-3082

Lelieveld HLM (1984) Mixed-strain continuous milk fermentation. Proc. Biochem. 19: 112-113

Lopes TS, Klootwijk J, Veenstra AE, Van der Aar PC, van Heerikhuizen H, Raué HA \& Planta RJ (1989) High-copy-number integration into the ribosomal DNA of Saccharomyces cerevisiae: a new vector for high-level expression. Gene 79: 199-206

Martegani E, Forlani N, Mauri I, Porro D, Schleuning WD \& Alberghina L (1992) Expression of high levels of human tissue plasminogen activator in yeast under the control of an inducible GAL promoter. Appl. Microbiol. Biotechnol. 37: 604-608

Mason CA \& Hamer G (1987) Cryptic growth in Klebsiella pneumoniae. Appl. Microbiol. Biotechnol. 25: 577-584

Mason CA (1991) Physiological aspects of growth and recombinant DNA stability in Saccharomyces cerevisiae. Antonic van Leeuwenhoek 59: 269-283

Matoba S \& Ogrydziak DM (1989) A novel location for dipeptidyl aminopeptidase processing sites in the alkaline extracellular protease of Yarrowia lipolytica. J. Biol. Chem. 264: 6037-6043

Murray AW \& Szostak JW (1983) Pedigree analysis of plasmid segregation in yeast. Cell 34: 961-970

Newmark P (1989) Danish law to be less rigid. Nature 339: 653
Nicaud JM, Fabre E \& Gaillardin C (1989) Expression of invertase activity in Yarrowia lipolytica and its use as a selective marker. Curr. Genet. 16: 253-260

Onken U \& Liefke E (1989) Effect of total and partial pressure (oxygen and carbon dioxide) on aerobic microbiol processes. Adv. Biochem. Eng. Biotechnol. 40: 137-169

Petrik M, Käppeli O \& Fiechter A (1983) An expanded concept for the glucose effect in the yeast Saccharomyces uvarum: involvement of short- and long-term regulation. J. Gen. Microbiol. 129: 43-49

Pirt SJ (1965) The maintenance energy of bacteria in growing cultures. Proc. Royal Soc. London 163B: 224-231.

Pirt SJ (1974) The theory of fed batch culture with reference to the penicillin fermentation. J. Appl. Chem. Biotechnol. 24: 415-424

Poldermans B (1989) Commerciële enzymen en koolhydraten. Koolhydraten in Nederland 5: 25-28

Postma E, Verduyn C, Scheffers WA \& van Dijken JP (1989) Enzymic analysis of the Crabtree effect in glucose-limited chemostat cultures of Saccharomyces cerevisiae. Appl. Env. Microbiol. 55: 468-477

Präve P, Schlingmann M, Crueger W, Esser K, Thauer R, Wagner F (1990) Übersicht über eine Auswahl der wichtigsten Substrate und Substrat-Kosten für die technische Fermentation (1989/1990). In: Jahrbuch Biotechnologie Band 3 (pp. 523-524) Carl Hanser Verlag, München.

Reiser J, Glumoff V, Kälin M \& Ochsner U (1990) Transfer and expression of heterologous genes in yeasts other than Saccharomyces cerevisiae, Adv. Biochem. Eng. Biotechnol. 43: 75-102

Roels JA (1983) Energetics and kinetics in biotechnology. Elsevier Science Publishers, Amsterdam

Roggenkamp R, Hansen H, Eckart M, Janowicz Z \& Hollenberg CP (1986) Transformation of the methylotrophic yeast Hansenula polymorpha by autonomous replication and integration vectors Mol. Gen. Genet. 202: 302-308

Romanos MA, Clare JJ, Beesley KM, Rayment FB, Ballantine SP, Makoff AJ, Dougan G, Fairweather NF \& Charles IG (1991) Recombinant Bordetella pertussis pertactin (p69) from the yeast Pichia pastoris: high-level production and immunological properties. Vaccine 9: 901-906

Romanos MA, Scorer CA \& Clare J (1992) Foreign gene expression in yeast: a review. Yeast 8: 423-488

Rossolini GM, Riccio ML, Gallo E \& Galeotti CL (1992)Kluyveromyces lactis rDNA as a target for multiple integration by homologous recombination. Gene 119: 75-81

Schultz LD, Hofmann KJ, Mylin LM, Montgomery DL, Ellis RW \& Hopper JE (1987) Regulated overproduction of the GALA gene product greatly increases expression from galactose-inducible promoters on multi-copy expression vectors in yeast. Gene 61: 123-133

Sledziewski AZ, Bell A, Kelsay K \& MacKay VL (1988) Construction of temperature-regulated yeast promoters using the MAT $\alpha 2$ repression system. Bio/Technology 6: 411-416

Sreekrishna K, Potenz RHB, Cruze JA, McCombie WR, Parker KA, Nelles L, Mazzaferro PK, Holden KA, Harrison RG, Wood PJ, Phelps DA, Hubbard CE \& Fuke M (1988) High level expression of heterologous proteins in methylotrophic yeast Pichia pastoris. J. Basic Micobiol. 28: 265-278

Sreekrishna K, Nelles L, Potenz R, Cruze J, Mazzaferro P, Fish W, Fuke M, Holden K, Phelps D, Wood P \& Parker K (1989) Highlevel expression, purification and characterization of recombinant human tumor necrosis factor synthesized in the methylotrophic yeast Pichia pastoris. Biochem. 28: 4117-4125 
Srienc F, Campbell JL \& Bailey JE (1986) Analysis of unstable recombinant Saccharomyces cerevisiae population growth in selection medium. Biotechnol. Bioeng. 28: 996-1006

Stouthamer AH \& Bettenhausen C (1973) Utilization of energy for growth and maintenance in continuous and batch cultures of microorganisms. A reevaluation of the method for the determination of ATP production by measuring molar growth yields. Biochim. Biophys. Acta 301: 53-70

Stouthamer AH \& van Verseveld HW (1985) Stoichiometry of microbial growth. In: Moo-Young M, Bull T \& Dalton H (Eds) Comprehensive Biotechnology Vol. 1 (pp. 215-238) Pergamon press, Oxford

Stouthamer AH \& van Verseveld HW (1987) Microbial energetics should be considered in manipulating metabolism for biotechnological purposes. Trends Biotechnol 5: 149-155

Terwisscha van Scheltinga AH (1990) General production methods. In: Gerhartz W (Ed) Enzymes in industry: production and application (pp. 33-43) VCH Verlaggesellschaft Weinberg, Germany

Tøttrup HV \& Carlsen S (1990) A process for the production of human proinsulin in Saccharomyces cerevisiae. Biotechnol. Bioeng 35: 339-348

Tschopp JF, Sverlow G, Kosson R, Craig W \& Grinna L (1987) High-level secretion of glycosylated invertase in the methylotrophic yeast, Pichia pastoris. Bio/Technology 5: 1305-1308

Turner BG, Avgerinos GC, Melnick LM \& Moir DT (1991) Optimization of pro-urokinase secretion from recombinant Saccharomyces cerevisiae. Biotechnol. Bioeng. 37: 869-875

Van den Berg JA, Van der Laken KJ, Van Ooyen AJJ, Renniers TCHM, Rietveld K, Schaap A, Brake AJ, Bishop RJ, Schultz K, Moyer D, Richman M \& Shuster JR (1990). Kluyveromyces as a host for heterologous gene expression: expression and secretion of prochymosin. Bio/Technology 8: 135-139

Van Dijken JP, Otto R \& Harder W (1976). Growth of Hansenula polymorpha in a methanol limited chemostat: physiological responses due to the involvement of methanol oxidase as a key enzyme in methanol metabolism. Arch. Microbiol. 111: 137-144

Van Dijken JP \& Scheffers WA (1986). Redox balances in the metabolism of sugars by yeasts. FEMS Microbiol. Rev. 32: 199 224
Van 't Riet K (1983) Mass transfer in fermentation. Trends Biotechnol. 1: 113-119

Van Urk H, Voll WSL, Scheffers WA \& Van Dijken JP (1990) Transient-state analysis of metabolic fluxes in Crabtree-positive and Crabtree-negative yeasts. Appl. Environ. Microbiol. 56: 281287

Van Verseveld HW, de Hollander JA, Frankena J, Braster M, Leeuwerik FJ \& Stouthamer AH (1986) Modeling of microbial substrate conversion, growth and product formation in a recycling fermentor. Antonie van Leeuwenhoek 52: 325-342

Veale RA, Giuseppin MLF, Van Eijk HMJ, Sudbery PE \& Verrips CT (1992) Development of a strain of Hansenula polymorpha for the efficient expression of guar $\alpha$-galactosidase. Yeast 8: 361-372

Veenhuis M, Van Dijken JP \& Harder W (1983). The significance of peroxisomes in the metabolism of one-carbon compounds in yeasts. Adv. Micr. Physiol. 24: 1-82

Verduyn C, Zomerdijk TPL, van Dijken JP \& Scheffers WA (1984) Continuous measurement of ethanol production by aerobic yeast suspensions with an enzyme electrode. Appl. Microbiol. Biotechnol. 19: 181-185

Verduyn C (1991) Physiology of yeasts in relation to growth yields. Antonie van Leewenhoek 60: 325-353

Verduyn C, Postma E, Scheffers WA \& Van Dijken JP (1992) Effect of benzoic acid on metabolic fluxes in yeast: a continuous culture study on the regulation of respiration and alcoholic fermentation. Yeast 8: 501-517

Walton EF \& Yarranton GT (1989) Negative regulation of gene expression by mating type. In: Walton EF \& Yarranton GT (Eds) Molecular and Cell Biology of Yeasts (pp. 43-69) Blackie and Van Nostrand Reinhold

Warner JR (1989) Synthesis of ribosomes in Saccharomyces cerevisiae. Microbiol. Rev, 53: 256-271

Yamada T \& Ogrydziak DM (1983) Extracellular acid proteases produced by Saccharomycopsis lipolytica. J. Bacteriol. 154: 2331

Yamanè T \& Shimizu S (1984) Fed-batch techniques in microbial processes. Adv. Biochem. Eng. Biotechnol. 30: 147-194 